\title{
Masalah Psikososial Anak dengan Penyakit Kanker Selama Pandemi COVID-19
}

\author{
Septri Nadya ${ }^{1}$, Hellena Deli ${ }^{1}$, Wasisto Utomo ${ }^{1}$ \\ ${ }^{1}$ Jurusan Keperawatan, Fakultas Keperawatan, Universitas Riau, Pekanbaru \\ Corresponding author: septrinadya@gmail.com
}

\begin{abstract}
ABSTRAK
Latar belakang: masalah psikososial merupakan permasalahan yang rentan terjadi pada anak kanker dan pandemi COVID-19 dapat menjadi salah satu faktor yang memperberat masalah psikososial anak dengan penyakit kanker tersebut.

Tujuan: penelitian ini bertujuan untuk melihat gambaran masalah psikososial anak dengan penyakit kanker selama pandemi COVID-19.

Metode: desain penelitian ini adalah deskriptif dengan jumlah responden sebanyak 28 orang. Teknik pengambilan sampel pada penelitian ini adalah purposive sampling. Penelitian ini menggunakan kuesioner yang sudah dilakukan uji validitas dan reliabilitas sebelumnya. Analisa data yang digunakan dalam penelitian ini adalah analisa univariat.

Hasil: hasil penelitian menunjukkan mayoritas 15 responden $(53,6 \%)$ memiliki nilai psikososial yang negatif. Hasil penelitian juga menunjukkan bahwa sebanyak 19 responden $(67,9 \%)$ mengalami kecemasan, 16 responden $(57,1 \%)$ mendapatkan dukungan sosial yang buruk, 17 responden $(60,7 \%)$ memiliki masalah sosial, 15 responden $(53,6 \%)$ mengalami gejala depresi dan 15 responden $(53,6 \%)$ memiliki body image yang buruk.

Simpulan: gambaran masalah psikososial anak dengan penyakit kanker selama pandemi COVID-19 menunjukkan bahwa sebagian besar responden memiliki hasil psikososial yang negatif.
\end{abstract}

\section{Kata kunci:}

Anak kanker; pandemi COVID-19; psikososial.

\section{ABSTRACT}

Background: psychosocial problems are problems that are prone to occur in children with cancer and the COVID-19 pandemic can be one of the factors that exacerbates the psychosocial problems of children with cancer.

Pupose: this study aims to describe the psychosocial problems of children with cancer during the COVID-19 pandemic.

Methods: the design of this research is descriptive with the number of respondents as many as 28 people. The sampling technique in this research is purposive sampling. This study uses a questionnaire that has been tested for validity and reliability before. The data analysis used in this research is univariate analysis.

Results: the results showed that the majority of 15 respondents (53.6\%) had negative psychosocial values. The results also showed that 19 respondents $(67.9 \%)$ experienced anxiety, 16 respondents $(57.1 \%)$ received poor social support, 17 respondents $(60.7 \%)$ had social problems, 15 respondents $(53.6 \%)$ ) experienced symptoms of depression and 15 respondents (53.6\%) had a bad body image 
Conclusion: the description of the psychosocial problems of children with cancer during the COVID-19 pandemic shows that most of the respondents have negative psychosocial outcomes.

\section{Keywords:}

Child cancer; the COVID-19 pandemic; psychosocial.

\section{LATAR BELAKANG}

Pandemi COVID-19 mengubah kehidupan seluruh penduduk terutama dalam hal kesehatan, keselamatan dan kesejahteraan setiap individu maupun komunitas. Kebijakan yang ditetapkan pemerintah dalam upaya menekan rantai penyebaran COVID-19 pun memberikan dampak terhadap anak seperti kebijakan stay at home, pembelajaran daring, social distancing, dan lain-lain (Tuwu, 2020). Anak menjadi kelompok yang lebih rentan dalam menerima dampak psikososial dari pandemi, karena anak berada dalam masa kritis tahap perkembangan (Miranda et al, 2020). Terutama pada anak dengan penyakit kronis, kehidupan seseorang dengan penyakit kronis akan mempengaruhi semua aspek kehidupannya, baik individu itu sendiri maupun individu yang berada di sekitarnya, tidak hanya aspek fisik tetapi juga psikologis dan emosional (Afitasari et al, 2014).

Salah satu penyakit kronis yang banyak diderita oleh anak di Indonesia adalah penyakit kanker. Kanker merupakan salah satu penyakit kronis dengan variasi yang paling lebar karena penyakit kanker sulit untuk dideteksi dan memerlukan pembiayaan yang besar (Kementerian Kesehatan Republik Indonesia, 2017). Berdasarkan data Global Cancer Observatory (2020) prevalensi kanker pada anak di Indonesia yang berumur 5 tahun mencapai angka 946.088. Kanker anak merupakan penyebab kematian nomor 2 pada anak dengan rentang usia 5-14 tahun. Anak dapat terserang kanker dari usia bayi hingga 18 tahun. Kanker yang dialami anak berbeda dengan kanker yang dialami orang dewasa karena kanker pada anak sulit untuk dicegah, hal tersebut terjadi karena anak pada umumnya belum mampu untuk mengemukakan apa yang dirasakannya (Kementerian Kesehatan Republik Indonesia, 2018).

Penanganan kanker pada anak dapat dilakukan dengan terapi biologi, terapi radiasi, kemoterapi, cryotherapy, transplantasi sumsum tulang, dan transplantasi sel darah perifer. Namun, tindakan yang paling banyak diambil pada anak adalah kemoterapi (Nurhidayah et al, 2016). Kemoterapi memberikan dampak pada fisik anak seperti kehilangan berat badan, rambut rontok, mual dan muntah, konstipasi serta anoreksia (Ranailla et al, 2017). Tidak hanya pada aspek fisik tetapi juga akan berdampak terhadap psikososial anak, dimana kemoterapi dapat mempengaruhi kualitas hidup anak, tumbuh kembang, emosional, timbulnya rasa cemas dan depresi serta terganggunya kebiasaan tidur (Musarezaie et al, 2014).

Psikososial merupakan situasi dimana individu mampu mengenali dan mengendalikan perasaan diri sendiri dan orang lain, serta kemampuan mengelola emosi yang dialami atau yang dirasakan dalam menghadapi stresor atau tuntunan (Nurvitasari et al, 2017). Penelitian mengenai psikososial di masa pandemi oleh Tsamakis et al (2020) yang menjabarkan bahwa dampak pandemi COVID-19 terhadap anak kanker tidak bisa diabaikan karena anak dengan kanker merasa khawatir dan lebih beresiko mengalami komplikasi yang parah, hal tersebut diungkapkan oleh sebagian besar anak kanker di Milan. Dampak psikologis yang dialami pasien kanker tidak hanya dari proses penyakitnya, tetapi juga dari berlakunya penjagaan jarak sosial dan tindakan-tindakan melindungi diri yang banyak dilakukan oleh pasien lain. 
Menurut Bogaarts et al (2011) pasien kanker dapat mengalami sejumlah masalah psikososial yang merupakan kombinasi antara masalah psikologis dan sosial seperti, kecemasan, gejala depresi, citra tubuh, dukungan sosial serta masalah sosial. Masalah psikososial ini dialami $10 \%$ hingga $50 \%$ pasien kanker segera setelah didiagnosis dan dilakukan perawatan. Dalam penelitian yang berbeda memaparkan bahwa tingkat prevalensi mulai dari 14\% hingga 54\% untuk gejala depresi dan prevalensi kecemasan mulai dari 8,6\% hingga $49 \%$.

Kondisi psikososial individu dapat dipengaruhi oleh kondisi sakit yang dialaminya, karena kondisi sakit yang dirasakan secara tidak langsung mempengaruhi pasien dalam melaksanakan tumbuh kembangnya. Ketidakmampuan untuk memenuhi kebutuhan dirinya sendiri dapat dilihat dari perasaan frustasi, mudah marah, dan perasaan tidak berguna. Hal tersebut akan mengakibatkan perhatian hanya tertuju pada dirinya sendiri dan akan menyebabkan perhatian pada orang lain berkurang sehingga timbul perasaan menyalahkan diri sendiri (Puspitasari, 2015).

\section{TUJUAN}

Penelitian ini dilakukan untuk mengetahui bagaimana gambaran masalah psikososial pada anak dengan penyakit kanker selama pandemi COVID-19.

\section{METODE}

Desain penelitian yang digunakan adalah deskriptif kuantitatif dengan analisis data univariat. Penelitian dilakukan di RSUD Arifin Achmad poli onkologi hematologi anak ruangan seruni dengan 28 anak penyakit kanker pada 23 Juni 2021 hingga 22 Juli 2021. Penelitian menggunakan kuesioner yang telah dilakukan uji valid dan reliabel. Pelaksanaan penelitian dilakukan dengan menerapkan protokol kesehatan.

\section{HASIL}

Tabel 1. Karakteristik responden

\begin{tabular}{lcc}
\hline \multicolumn{1}{c}{$\begin{array}{c}\text { Karakteristik } \\
\text { Responden }\end{array}$} & $\begin{array}{c}\text { Frekuensi } \\
(f)\end{array}$ & $\begin{array}{c}\text { Presentase } \\
(\%)\end{array}$ \\
\hline Usia (Tahun) & & \\
a. Pra sekolah & 13 & 46,4 \\
b. Sekolah & 15 & 53,6 \\
\hline Jenis Kelamin & & \\
a. Laki-laki & 18 & 64,3 \\
b. Perempuan & 10 & 35,7 \\
\hline Diagnosa Kanker & & 75,0 \\
a. Leukemia & 21 & 3,6 \\
b. Kanker testis & 1 & 3,6 \\
c. Kanker PNET & 1 & 10,7 \\
d. RMS & 3 & 3,6 \\
e. NHL & 1 & 3,6 \\
f. Yolk sac tumor & 1 & 42,9 \\
\hline Lama Terdiagnosa & & 57,1 \\
a. $\leq 1$ tahun & 12 & 0 \\
b. > 1 tahun & 16 & \\
\hline Jenis Pengobatan & & \\
a. Kemoterapi & 28 & \\
b. Radioterapi & 0 & \\
\hline
\end{tabular}


Tabel diatas menunjukkan bahwa dari 28 responden, sebagian besar responden berada pada usia sekolah dengan jumlah 15 responden $(53,6 \%)$, mayoritas responden berjenis kelamin laki-laki dengan jumlah 18 responden $(64,3 \%)$, diagnosa medis yang paling banyak diderita oleh responden adalah leukemia dengan jumlah 21 responden $(75,0 \%)$, sebanyak 16 responden $(57,1 \%)$ sudah terdiagnosa kanker sejak lebih dari satu tahun lalu dan jenis pengobatan yang dijalani adalah kemoterapi dengan jumlah 28 responden $(100,0 \%)$.

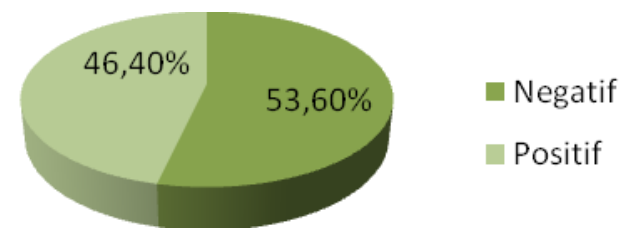

Diagram 1. Gambaran masalah psikososial anak dengan penyakit kanker selama pandemi COVID-19.

Hasil dari penelitian yang telah dilakukan pada 28 responden didapatkan bahwa sebanyak 13 responden (46,4\%) memiliki nilai psiksosial positif dan sebanyak 15 responden $(53,6 \%)$ memiliki nilai psikososial negatif.

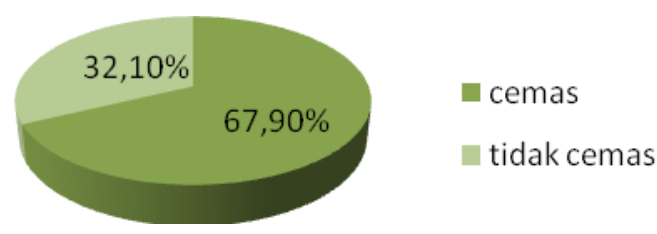

Diagram 2. Gambaran masalah psikosoial berdasarkan subskala kecemasan.

Hasil penelitian yang telah dilakukan pada 28 responden didapatkan bahwa sebanyak 19 responden $(67,9 \%)$ merasa cemas, sedangkan 9 responden $(32,1 \%)$ tidak merasa cemas.

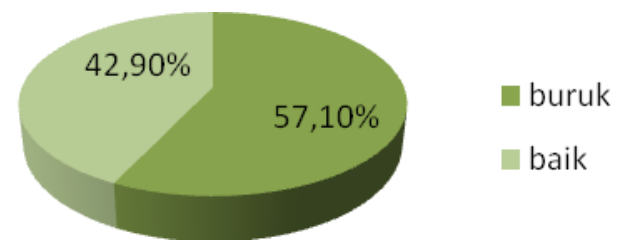

Diagram 3. Gambaran masalah psikosoial berdasarkan subskala dukungan sosial.

Hasil penelitian yang telah dilakukan pada 28 responden didapatkan bahwa sebanyak 16 responden $(57,1 \%)$ mendapatkan dukungan sosial yang buruk sedangkan 12 responden $(42,9 \%)$ mendapatkan dukungan sosial yang baik. 


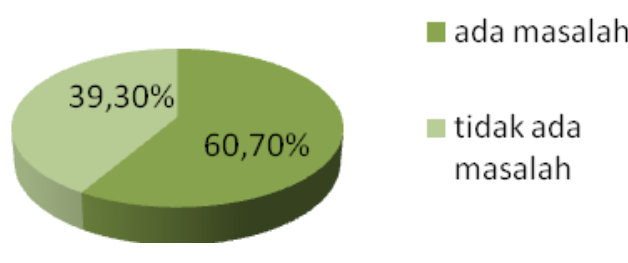

Diagram 4. Gambaran masalah psikosoial berdasarkan subskala masalah sosial

Hasil penelitian yang telah dilakukan pada 28 responden didapatkan bahwa sebanyak 17 responden $(60,7 \%)$ memiliki masalah sosial sedangkan 11 responden $(39,3 \%)$ tidak memiliki masalah sosial.

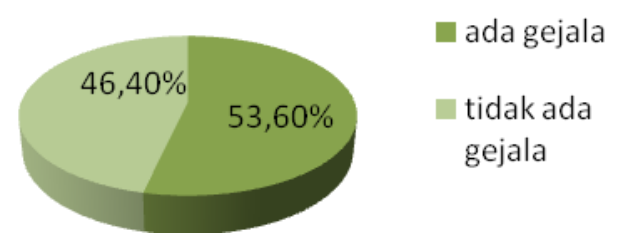

Diagram 5. Gambaran masalah psikosoial berdasarkan subskala gejala depresi.

Hasil penelitian yang telah dilakukan pada 28 responden didapatkan bahwa sebanyak 15 responden $(53,6 \%)$ memiliki gejala depresi sedangkan 13 responden $(46,4 \%)$ tidak memiliki gejala depresi.

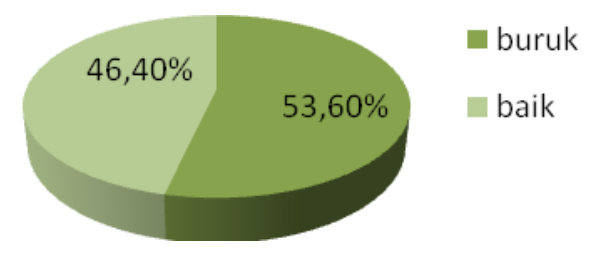

Diagram 6. Gambaran masalah psikosoial berdasarkan subskala body image.

Hasil penelitian yang telah dilakukan pada 28 responden didapatkan bahwa sebanyak 15 responden $(53,6 \%)$ memiliki body image yang buruk sedangkan 13 responden $(46,4 \%)$ memiliki body image yang baik.

\section{PEMBAHASAN}

Masalah psikososial yang dialami anak kanker tidak hanya sebatas proses penyakitnya, tetapi juga berkaitan dengan pembatasan sosial di lingkungan. Pandemi COVID-19 memberikan dampak yang tidak dapat diabaikan terhadap anak kanker sebab anak dengan penyakit kanker lebih beresiko tinggi mengalami komplikasi yang parah, hal tersebut dijabarkan dalam penelitian yang dilakukan oleh Tsamakis et al (2020) dimana sebagian besar anak kanker di Milan merasa khawatir akan terpapar COVID-19. Penelitian yang dilakukan oleh van Gorp et 
al (2021) didapatkan penurunan nilai fungsi psikososial jika dibandingkan dengan sebelum pandemi COVID-19.

Mayoritas ahli onkologi anak (81,0\%) menyatakan bahwa pembatasan ketat untuk bersekolah akan menghasilkan masalah psikososial yang serius, sedangkan $(19,0 \%)$ dari ahli onkologi menyatakan bahwa masalah psikososial akan ada tetapi tidak serius (Simon et al, 2021). Sedangkan pada hasil penelitian ini yang ditunjukkan pada diagram 1, jika dilihat secara keseluruhan didapatkan sebanyak 15 responden $(53,6 \%)$ memiliki nilai psikososial negatif.

Pada diagram 2 hingga 6 yang ditampilkan menunjukkan subskala dari permasalahan psikososial yang dapat terjadi pada anak dengan penyakit kanker. Diagram 2 menjelaskan bahwa mayoritas dari responden merasakan cemas, Hal ini sebanding dengan hasil penelitian yang didapatkan oleh Putri et al (2020) dimana dari 30 responden yang diteliti, 23 responden (76,7\%) mengalami kecemasan berat. Pada umumnya, kecemasan yang timbul pada sebagian pasien dengan kanker sangat beragam dan berhubungan erat dengan proses pengobatannya. Reaksi tersebut sangat manusiawi dan merupakan suatu kenyataan yang harus dihadapi (Fauziah, 2019). Setiap prosedur dalam perawatan dan pengobatan anak dengan kanker adalah keadaan situasional yang berhubungan dengan kecemasan. Setiap pasien kanker memiliki reaksi yang berbeda dan tidak sama bila dihadapkan dengan kecemasan (Negara et al, 2014).

Pada diagram 3 menunjukkan hasil bahwa sebagian besar responden menerima dukungan sosial yang buruk. Hal ini tidak sejalan dengan penelitian yang dilakukan oleh Negara et al (2014) dimana hasil yang didapat adalah sebanyak 16 responden (53,3\%) mendapat dukungan sosial yang positif. Psikososial pada anak dapat dipengaruhi oleh faktor dukungan sosial, jika anak mendapatkan dukungan sosial yang baik maka risiko terjadinya gangguan sosial semakin kecil (Nakajima-Yamaguchi et al, 2016). Pengaruh dukungan sosial terhadap anak berdampak kepada penyesuaian terhadap kejadian dalam kehidupan yang dapat mengakibatkan stres karena banyaknya tekanan psikologis saat pengobatan dilakukan (Negara et al, 2014).

Diagram 4 memaparkan bahwa mayoritas responden memiliki masalah sosial, Hal ini sejalan dengan hasil penelitian Alshahrani et al (2020) dimana dari 204 responden anak yang diteliti didapat $(81,3 \%)$ mengalami masalah sosial selama pandemi hal ini terjadi karena keterbatasan dalam aktivitas sosial, isolasi sosial, perasaan takut dan sendirian. Pada umumnya anak dengan kanker memiliki permasalahan sosial yang berkaitan dengan kehilangan teman sebaya. Hal ini bergantung pada usia saat diagnosis kanker dan lamanya pengobatan. Jika pengobatan menyebabkan dampak tertentu pada anak, maka akan menyebabkan dampak yang lebih besar pada penyesuaian sosial di lingkungan anak. Menyesuaiakan diri dengan teman sebaya sangat terkait dengan perasaan percaya diri anak dalam situasi sosial. Anak yang menjalani pengobatan akan kehilangan banyak kesempatan untuk mempraktikkan interaksi sosial, sehingga akan membuatnya sulit dalam memulai dan mengikuti percakapan dan memahami humor (Barbach et al, 2013).

Pada diagram 5 menjelaskan bahwa sebagian besar responden memiliki gejala depresi, Hal ini sejalan dengan penelitian yang dilakukan oleh Li et al (2013) dimana sebesar $(52,6 \%)$ responden menunjukkan potensi mengalami depresi dan menunjukkan beberapa gejala depresi yang diukur dengan CES-DS. Depresi dapat terjadi pada semua jenis kanker dan pada setiap tahap penyakit. Anak dengan permasalahan penyakit kronis memiliki resiko yang lebih tinggi jika dibandingkan dengan anak yang sehat, meskipun tingkat depresi yang terjadi belum termasuk klinis (Asyanti, 2013). Penyakit kronis dapat menyebabkan peningkatan 
prevalensi terjadinya depresi hingga 20\% jika dibandingkan dengan individu yang sehat. Hal tersebut dapat terjadi karena rentannya anak terhadap depresi dan peristiwa hidup yang anak alami bersifat negatif bahkan terjadi bersamaan dengan penyakit yang dideritanya (Irwanto, 2020).

Diagram 6 menggambarkan bahwa mayoritas responden memiliki body image yang buruk, Hasil penelitian ini tidak serupa dengan Muliadi (2015) dimana sebanyak 27 responden (67,5\%) memandang positif citra tubuh yang ada pada dirinya. Seseorang dengan body image yang baik memiliki persepsi positif tentang dirinya, sehingga seseorang tersebut akan menerima kondisi fisik dan secara efektif akan memanfaatkannya. Body image yang baik dapat mempengaruhi kemampuan untuk saling berkomunikasi dengan teman sebaya dan memiliki rasa percaya diri yang kuat saat bertemu orang asing (Lestari, 2013). Penyakit kanker pada anak menyebabkan perubahan tubuh baik karena penyakit kanker itu sendiri ataupun dari efek pengobatan yang dilakukan. Anak dengan kanker memiliki penilaian dan cara pandang tersendiri melihat tubuh dan penyakitnya (Sulistyanti et al, 2012).

\section{KESIMPULAN}

Berdasarkan hasil penelitian yang telah dilakukan dapat disimpulkan bahwa sebagian anak dengan kanker yang memiliki nilai psikososial negatif. Jika dilihat dari permasalahan psikososialnya, sebagian dari anak yang menjadi responden dalam penelitian mengalami kecemasan, mendapatkan dukungan sosial yang buruk, dan sebagian besar anak dengan kanker memiliki masalah sosial, sebagian besar dari responden pun memiliki gejala depresi serta memiliki body image yang buruk. Hal ini dapat dipengaruhi oleh dukungan sosial yang diterima anak dari orang tua dan lingkungan terdekatnya, sehingga baik atau buruknya penerimaan diri anak dengan penyakit kanker bergantung pada hal tersebut. Hasil dari penelitian ini dapat menjadi sumber referensi bagi peneliti berikutnya yang berhubungan dengan gambaran psikososial dan penyakit kanker pada anak selama pandemi COVID-19.

\section{REFERENSI}

Afitasari, Sofyani, S., \& Mutiara, E. (2014). Perbandingan gangguan perilaku anak penderita penyakit jantung bawaan dan saudaranya yang sehat. Sari Pediatri, 16(1), 53-56.

Alshahrani, M., Elyamany, G., Sedick, Q., Ibrahim, W., Mohamed, A., Othman, M., Al Thibani, N., Alsuhaibani, O., Al Amro, M., Gharawi, A., Al Sharif, O., Elborai, Y., Alabbas, F., Binhassan, A., AlMoshary, M., Al Mussaed, E., \& Alkhayat, N. (2020). The Impact of COVID-19 Pandemic in Children With Cancer: A Report From Saudi Arabia. Health Services Insights, 13. https://doi.org/10.1177/1178632920984161

Asyanti, S. (2013). Dinamika permasalahan pada orangtua yang memiliki anak dengan penyakit kronis dan tantangannya dalam mengantarkan anak menjadi pribadi yang lebih sehat dan berkarakter tangguh. Fakultas Psikologi Universitas MUhammadiyah Surakarta, 214-224.

Barbach, N., Gallo-Silver, L., Hicks, M., Jones, B., Klein, L., Lauria, M. M., Lustig, C., McKinley, K., Moore, T., Smart, E., \& Vasser, E. (2013). Childhood Cancer Survivorship : an Overview for Social Workers. National Association of Social Workers.

Bogaarts, M. P. J., Oudsten, B. L. Den, Roukema, J. A., Riel, J. M. G. H. Van, Beerepoot, L. V., \& Vries, J. De. (2011). Development of the psychosocial distres questionnaire-breast cancer (PDQ-BC): a breast cancer-spesific screening instrument for psycosocial problems. In Support Care Cancer (Vol. 19, pp. 1485-1493). https://doi.org/10.1007/s00520-010-0968-9

Fauziah, R. N. (2019). Kecemasan Pada Penderita Kanker. Naskah Publikasi, 53(9), 16891699. 
Global Cancer Obsevatory. (2020). Indonesia source: Globocan 2020 (Vol. 858, pp. 1-2). World Health Organization. https:/gco.iarc.fr/today/data/factsheets/populations/360indonesia-fact-sheets.pdf

Irwanto. (2020). Hubungan pola komunikasi, daya koping, dan stres pada orang tua dengan luaran anak penderita kanker.

Kementerian Kesehatan Republik Indonesia. (2018). Kenali gejala dini kanker pada anak. http://www.p2ptm.kemkes.go.id/kegiatan-p2ptm/pusat-/kenali-gejala-dini-kanker-padaanak

Kementrian Kesehatan Republik Indonesia. (2017). Pencegahan dan pengendalian penyakit tidak menular (pp. 1-37). http://p2p.kemkes.go.id/wpcontent/uploads/2017/12/P2PTM_RAK2017.pdf

Lestari, S. (2013). Hubungan antara lamanya kemoterapi dengan body image pasien leukemia limfosit akut pada anak pra sekolah di rsud Dr. Moewardi di Surakarta.

Miranda, D. M. de, Athanasio, B. da S., Oliveira, A. C. S., \& Simoes-e-Silva, A. C. (2020). How is COVID-19 pandemic impacting mental health of children and adolescents? International Journal of Disaster Risk Reduction, 51(September), 101845. https://doi.org/10.1016/j.ijdrr.2020.101845

Muliadi, D. (2015). Gambaran citra tubuh dan depresi pada remaja penderita kanker leukemia. Universitas Sumatera Utara, 7-37.

Musarezaie, A., Khaledi, F., Esfahani, H. N., \& Ghaleghasemi, T. M. (2014). Factors affecting quality of life and fatigue in patients with leukemia under chemotherapy. Journal of Education and Health Promotion, 3(1), 64-64. https://doi.org/10.4103/22779531.134778

Nakajima-Yamaguchi, R., Morita, N., Nakao, T., Shimizu, T., Ogai, Y., Takahashi, H., Saito, T., Nakatani, Y., \& Fukushima, T. (2016). Parental post-traumatic stress symptoms as predictors of psychosocial problems in children treated for cancer. International Journal of Environmental Research and Public Health, 13(8), 1-12. https://doi.org/10.3390/ijerph13080812

Negara, I. Z. C., Indriati, G., \& Nauli, F. A. (2014). Hubungan dukungan keluarga dengan tingkat kecemasan pada anak leukemia akibta kemoterapi di RSUD Arifin Achmad Provinsi Riau. Program Studi Ilmu Keperawatan, 59(9-10).

Nurhidayah, I., Hendrawati, S., S. Mediani, H., \& Adistie, F. (2016). Kualitas Hidup pada Anak dengan Kanker. Jurnal Keperawatan Padjadjaran, 4(1), 45-59. https://doi.org/10.24198/jkp.v4n1.5

Nurvitasari, J., Mardhiyah, A., \& Nurhidayah, I. (2017). Masalah psikososial pada penyandang talasemia usia sekolah di poliklinik talasemia RSUD Sumedang. Jurnal Fakultas Keperawatan Padjajaran, 55-63.

Puspitasari, E. (2015). Gambaran masalah keperawatan psikososial di ruang gayatri RS Marzuki Mahdi Bogor. Jurnal Keperawatan Jiwa, 3(2), 162-167.

Putri, P. A., Kadek, C. U., \& Juniartha, I. G. N. (2020). Gambaran Tingkat Kecemasan Pada Anak Kanker Sebelum Menjalani Kemoterapi Di Rumah Singgah Yayasan Peduli Kanker Anak Bali. Coping: Community of Publishing in Nursing, 8(3), 243. https://doi.org/10.24843/coping.2020.v08.i03.p04

Ranailla, R., Mardhiyah, A., \& Hidayati, N. O. (2017). Dampak kemoterapi pada anak penderita kanker di rumah cinta bandung. Jurnal Keperawatan Aisyiyah, 4(6), 41-53.

Simon, A., Siebald, B., Stamm, W., Graf, N., Meier, S., Schrappe, M., Groll, A. H., Laws, H., \& Lehrnbecher, T. (2021). School and kindergarten attendance and home schooling of pediatric cancer patients before and during the SARS-CoV-2 pandemic: results of a survey of the German Society for Pediatric Oncology and Hematology. GMS Hygene and Infection Control, 16(2196-5226), 2-6. 
Sulistyanti, D., Keperawatan, F. I., \& Sarjana, P. S. (2012). Universitas Indonesia Studi Deskriptif Konsep Diri Anak Usia Sekolah Wilayah Jakarta Dan Sekitarnya Universitas Indonesia.

Tsamakis, K., Gavriatopoulou, M., Schizas, D., Stravodimou, A., Mougkou, A., Tsiptsios, D., Sioulas, V., Spartalis, E., Sioulas, A. D., Tsamakis, C., Charalampakis, N., Mueller, C., Arya, D., Zarogoulidis, P., Spandidos, D. A., Dimopoulos, M. A., Papageorgiou, C., \& Rizos, E. (2020). Oncology during the COVID-19 pandemic: Challenges, dilemmas and the psychosocial impact on cancer patients (Review). Oncology Letters, 20(1), 441-447. https://doi.org/10.3892/ol.2020.11599

Tuwu, D. (2020). Kebijakan Pemerintah Dalam Penanganan Pandemi Covid-19. Journal Publicuho, 3(2), 267. https://doi.org/10.35817/jpu.v3i2.12535

van Gorp, M., Maurice-Stam, H., Teunissen, L. C., van de Peppel-van der Meer, W., Huussen, M., Schouten-van Meeteren, A. Y. N., \& Grootenhuis, M. A. (2021). No increase in psychosocial stress of Dutch children with cancer and their caregivers during the first months of the COVID-19 pandemic. Pediatric Blood and Cancer, 68(2), 1-5. https://doi.org/10.1002/pbc.28827 